\title{
Research on some technical aspects of outdoor recreation, as part of multipurpose rural reconstructions in the Netherlands
}

\author{
H. N. van Lier
}

Institute for Land and Water Management Research, Wageningen, the Netherlands

Received: 14 November 1971

\section{Summary}

Outdoor recreation in the Netherlands has become a major problem because of the increasing demand and a relative lag in adequate facilities.

One of the possibilities to create new projects is via multipurpose rural reconstruction programs.

In this context three major groups of problems have been distinguished: location, capacity, and layout problems.

The determination of the right location is to be based on the recreation patterns (demand and preferences), and on the properties of the landscape. A quantitative information about the future demand can be given by model studies, in which demand, use and gravity models are now commonly used. The value of the landscape can be determined in different ways. One of the systems at present in use has been described.

The calculation of the design capacity can be done with the above-mentioned models, with the restriction that the location of the new project is already known.

The layout of the new project has to be based on the behavior and preferences of the visitors and on the technical possibilities (physical constraints). In both fields the research has just started.

Future research is desired in the following fields: a nation-wide statistical origin research; project research; layout research; landscape evaluation systems.

\section{Introduction}

In the Netherlands - as in most western countries - the demand for outdoor recreation is rapidly growing as a result of a change in generally recognized society variables': increasing population, rising incomes, greater mobility and more paid vacations. This phenomenon gives rise to quite a lot of problems when it occurs in one of the most densely populated countries in the world ( 400 persons per $\mathrm{km}^{2}$ on the average). Such a situation causes a rapidly increasing imbalance between supply and demand regarding recreation facilities.

The natural recreation areas are situated too far away from the major towns for short recreational use, are outdated or have reached their full capacity. This results in a social and political pressure to create new facilities, most of which have to be created in rural areas. For that reason there is an increasing coherence between programs for outdoor recreation and programs for modern agricultural development via rural reconstruction schemes. 
Rural reconstruction programs - started in 1924 for concentration of agricultural holdings with scattered parcellation - have since World War II changed into regionwide multipurpose rural reconstruction schemes, in which many non-agrarian purposes (construction of highways and other roads connecting urban centers, scenery plans, nature conservancies, and so on) are incorporated. Some figures can give an insight into the scale in which these operations are carried out. From the 2.2 million ha under cultivation in the Netherlands, approximately one third has been reconstructed, another third is in execution or in an active preparation stage, while for the last third rural reconstructions have been applied for by the land-owners.

At this scale of operations and with government backing quite a lot can be done in creating outdoor recreation facilities (e.g. artificial lakes, scenic roads, cycle paths, bridle paths, footpaths, playgrounds and picnic sites) within the framework of a rural reconstruction scheme.

Emphasis has been laid on day and weekend recreation. It may be expected, however, that facilities for vacational recreation will be included.

As has long been realized in many countries, the problem can be profitably considered as an (im)balance between supply and demand. The analysis of supply and demand can be done on a nation-wide, a regional or a local scale depending upon what type of recreation (plan) is under consideration.

According to the generally accepted principle of working from large towards small', general reconnaissance studies have been made in the past decades to indicate the direction of the new developments (Anon., 1961; Anon., 1966; Wippler, 1966). These studies resulted in an estimate of the percentage of people that leave town on a summer sunday of reasonably fine weather. This percentage varied between 25 and $40 \%$. Furthermore the destination of the trip was analysed. From this could be concluded that $60 \%$ of these recreationists are 'enjoying nature', $30 \%$ are visiting family, $4 \%$ are going in for outdoor sports and $6 \%$ have other interests. On the average $10 \%$ of the population leaves town for a weekend vacation. In the Netherlands 45 to $50 \%$ of the population take their vacation away from home.

This type of research gives only a first quantitative information on the present participation in outdoor recreation. For the planning of projects - taking high investments and management costs, and with a lifetime of 25 to 30 years - there is a strong need, however, for prognoses on the estimated participation in the different types of outdoor recreation. Therefore the development of research techniques making it possible to predict free time behavior patterns is essential. Prognostica as science may offer new perspectives in this respect (Jantsch, 1967; Polak, 1969).

\section{Scope of this article}

In this article some problems on the construction of new outdoor recreation facilities in rural areas are dealt with.

In a logical sequence the following major points can be distinguished:

- determination of the correct location of the project

- determination of the design capacity of the project

- layout of the project

As many forms of outdoor recreation are preferably connected with a beautiful landscape, the interrelationship between human beings and environment is the basis of all considerations. Therefore landscape analysis as well as analysis of human reaction 
upon physical-geographical structures have to be studied. Recently there is a 'boom' in literature on landscape analysis resulting from the general fear of destroying natural resources bij technological progress (see for example McHarg, 1969).

For the prediction of the number of visitors studies have to be made of the increase in regional population and of the relationship between participation in outdoor recreation and a number of socio-economic factors of groups of visitors, such as income, age, profession and family-phase.

To solve the third group of problems, the preferences of people for the layout of facilities inside the project will have to be analysed. Up to now only few results of such research are available.

Summarized the following scheme can be made (van Lier, 1970d):

a. location problems

1. physical-geographical features of the area

2. number and location of the towns

3. number and location of existing alternative sites

4. accessibility

b. capacity problems

1. frequency analysis for the determination of a normative year and a normative day

2. estimation of present and future demand for different types of outdoor recreation

3. relationship between participation and socio-economic factors

4. changes in recreational behavior (trends and mutations)

c. layout problems

1. analysis of use of facilities

2. changes in behavior

3. relationship between layout (luxury) and number of visitors.

There are of course correlations between these aspects. The correlations are based on the interaction of supply and demand determinants. It will be one of the major aims of recreation research to solve these problems in order to allocate funds efficiently and ultimately for the welfare of society.

\section{Location problems}

\section{Physical-geographical features of the area}

The evaluation of landscape characteristics for different types of outdoor recreation makes a rapid progress (Edminster, 1966; Hellywell, 1969; Kiemstedt, 1969; Segers, 1970; A. L. M. van Wijk, 1970).

The systems developed bij Segers (1970) and A. L. M. van Wijk (1970) are based on the systems of the Soil Conservation Service, but are adapted to the characteristics of landscapes and behavior patterns in the Netherlands.

This system is based upon the relative importance of geophysical characteristics for different types of outdoor recreation. These characteristics, called key elements, receive a weight or multiplier $(\mathrm{g})$ in a scale from 0 through 5 . The next phase is an inventory of the area on the quality or rate $(\mathrm{k})$ of these key elements, which is ranged in a scale 0 through 10 . Multiplying $\mathrm{g}$ and $\mathrm{k}$ and summation to $\Sigma \mathrm{gk}$ gives a score. This score gives an indication of the potential suitability of the area for the type of outdoor recreation under regard.

Table 1 gives an example of the SCS system (Edminster, 1966). 
Table 1. Example of the SCS system for the determination of 'potentials of an area for water sports (after Edminster, 1966).

\begin{tabular}{|c|c|c|c|}
\hline Area properties & $\begin{array}{l}\text { Multiplier } \\
\text { number }\end{array}$ & $\begin{array}{l}\text { Rating } \\
\text { number }\end{array}$ & Score \\
\hline Climate & 1 & 7 & 7 \\
\hline Scenery & 1 & 9 & 9 \\
\hline $\begin{array}{l}\text { Water areas } \\
\text { existing* } \\
\text { inland sites* }\end{array}$ & $\begin{array}{l}4 \\
3\end{array}$ & $\begin{array}{r}10 \\
2\end{array}$ & $\begin{array}{r}40 \\
6\end{array}$ \\
\hline $\begin{array}{l}\text { Population of people } \\
\text { size and distribution } \\
\text { age and occupation }\end{array}$ & $\begin{array}{l}2 \\
1\end{array}$ & $\begin{array}{l}7 \\
5\end{array}$ & $\begin{array}{r}14 \\
5\end{array}$ \\
\hline $\begin{array}{l}\text { Proximity and access } \\
\text { proximity to urban centres }\end{array}$ & 1 & 10 & 10 \\
\hline Totals & 13 & $S_{\text {act }}$ & 91 \\
\hline$S_{\max }=13 \times 10=130 \quad S_{a c}$ & Suital & ility $=100 \times$ & $\frac{91}{130}=70 \%$ \\
\hline
\end{tabular}

* Possible limiting factors.

The system adapted for the Netherlands (Segers, 1970) has been applied for the 'Drunense Duinen', and area of sand dunes between two cities in the southern part of the country, Tilburg and 's-Hertogenbosch. The results of this application for six types of outdoor recreation is shown in Table 2.

The results of the analysis show for this region only small differences between the scores for the different outdoor recreation types.

A shortcoming of this system is that there is no separation between landscape characteristics and demand factors (distance to towns, accessibility). For a better insight in the physiographic conditions a separation of these aspects seems to be indicated. A case-study has therefore been made, in which the potential suitability of an area is evaluated in two parts:

- a supply part: the physiographic properties of the area

- a demand part: the population in the region.

For a better evaluation of the landscape features some factors had to be distinguished in more detail (C. van Wijk, 1970). Table 3 gives the results.

With this system the suitability for a number of outdoor recreation types has been

Table 2. Results of the application of the adapted SCS system for the Drunense Duinen area (after Segers, 1970).

\begin{tabular}{llll}
\hline Type of outdoor recreation & Maximum score & Actual score & Suitablility (\%) \\
1. Sports and playing & 165 & 124 & 75 \\
2. Picnicing & 185 & 134.5 & 72 \\
3. Camping (shelter, caravan) & 190 & 127.5 & 67 \\
4. Staying in recreational lodges & 205 & 138 & 67 \\
5. Walking for pleasure & 180 & 132.5 & 74 \\
6. Bicycling & 165 & 119.5 & 72 \\
\hline
\end{tabular}


Table 3. Physiographic subdivision for outdoor recreation potentials (after C. van Wijk, 1970).

\begin{tabular}{ll}
\hline Climate & - macroclimate (clouds, temperature, etc.) \\
Landscape & - microclimate \\
& - high vegetation (hedges, woods, trees, etc.) \\
& - relief \\
& - parcellation \\
& - open water \\
& - built-up area \\
& - flora and fauna \\
& - unvisible elements (groundwater, soil, etc.)
\end{tabular}

determined for the Volthe-De Lutte area of 8.000 ha in the eastern part of the Netherlands, for which a rural reconstruction scheme has been applied. An example is given in Fig. 1 for driving for pleasure.

The properties of the population

From the point of demand the following factors have to be analysed:

- participation rate (day, weekend and vacation recreation)

- distribution according to travel distances (especially for analysis of day recreation)

- preferences for different recreation types.

In the solution of these problems two levels of approach can be indicated:

- a relative simple calculation scheme in which figures derived from studies are introduced, to get a first estimation of participants in a certain type of outdoor recreation

- the derivation of demand, use and gravity models in which socio-economic determinants, regression analysis and traffic theorems are used.

In the more detailed approach the results are also useful for the determination of the capacity of the project.

In the example of Volthe-De Lutte a demand calculation has been carried out. The results are given in Fig. 2 for driving for pleasure.

Finally a suitability-potential map has been constructed based on landscape suitability (supply) and calculated demand. An example is given in Fig. 3 for driving for pleasure in the Volthe-De Lutte area.

\section{Capacity problems}

In the preparation of new projects for outdoor recreation a major point is always the capacity of the project as a whole and of the separate facilities. This problem is analogous to that of other projects dealing with statistic phenomena as waterways, roads and so on.

To find the 'normative visit' ( $=$ number of visitors upon which the capacity of the new project should be based), three kinds of analyses should be carried out:

- analysis of the demand for that specific new project

- analysis of the relation between visit and weather

- analysis of the visit frequency curve. 


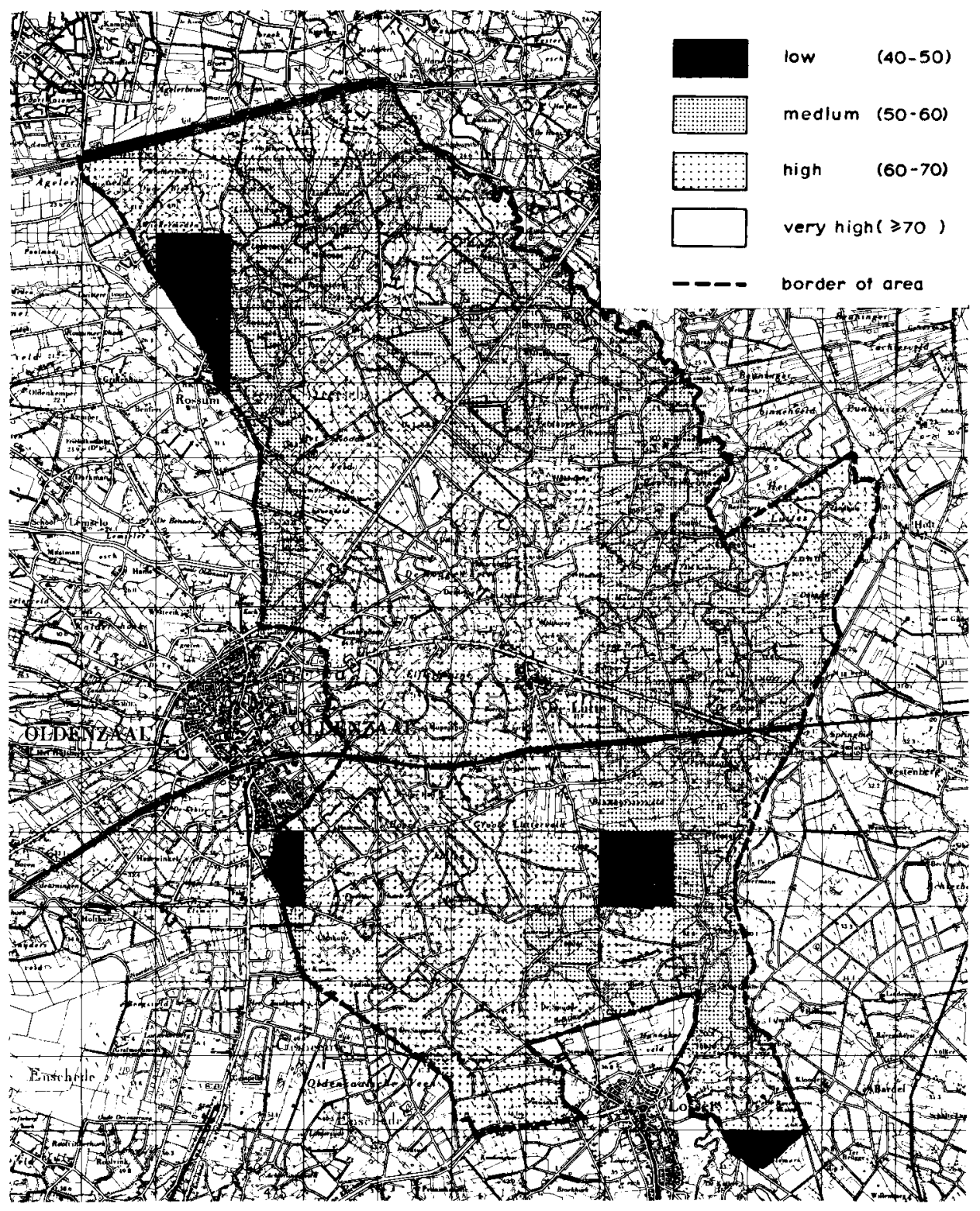

Fig. 1. Suitability classes for driving for pleasure, based on an analysis of landscape characteristics (supply), in the Volthe-De Lutte area (after Anon., 1971). 


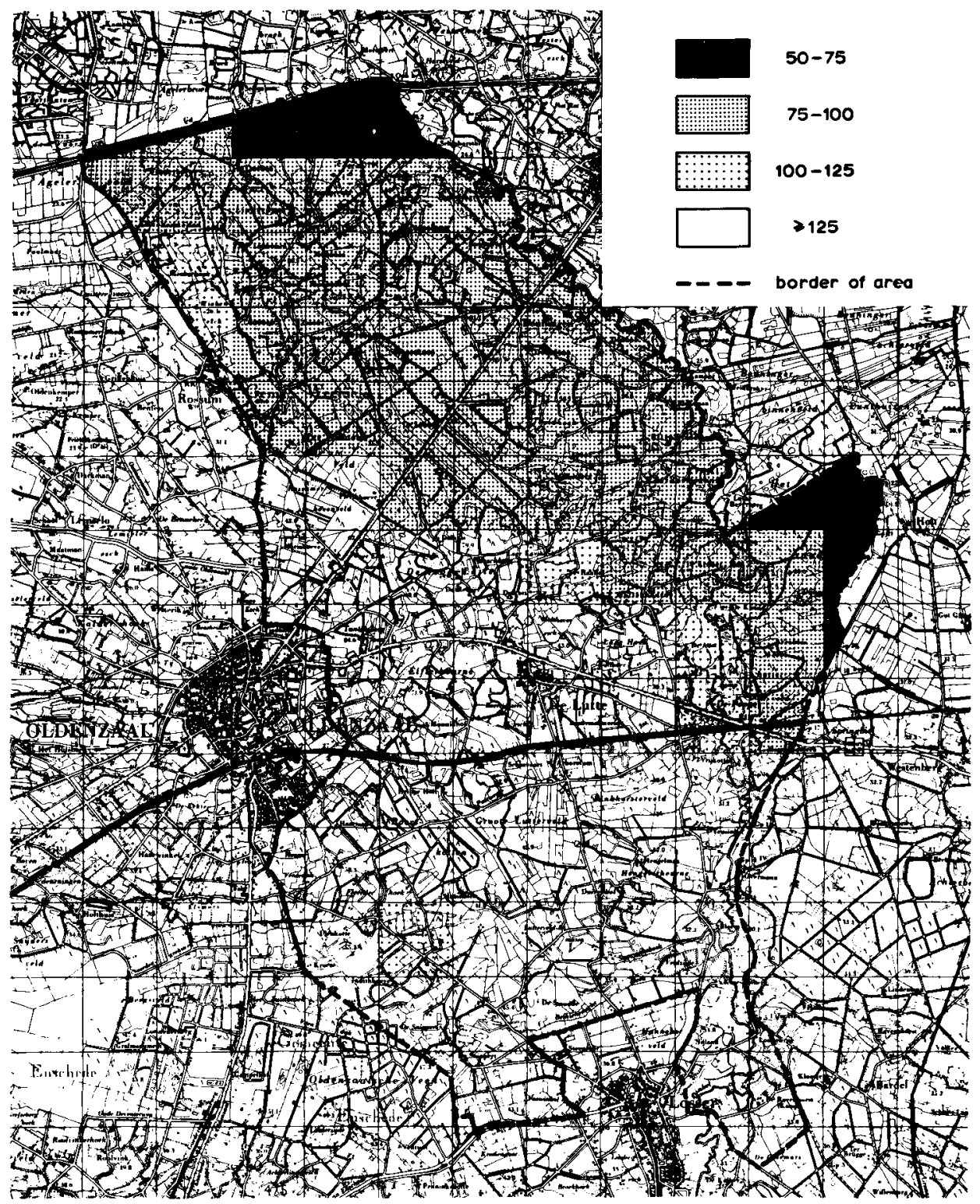

Fig. 2. Number of visitors per 100 ha for driving for pleasure expected in 1980 , based on a demand analysis, in the Volthe-De Lutte area (after Anon., 1971). 


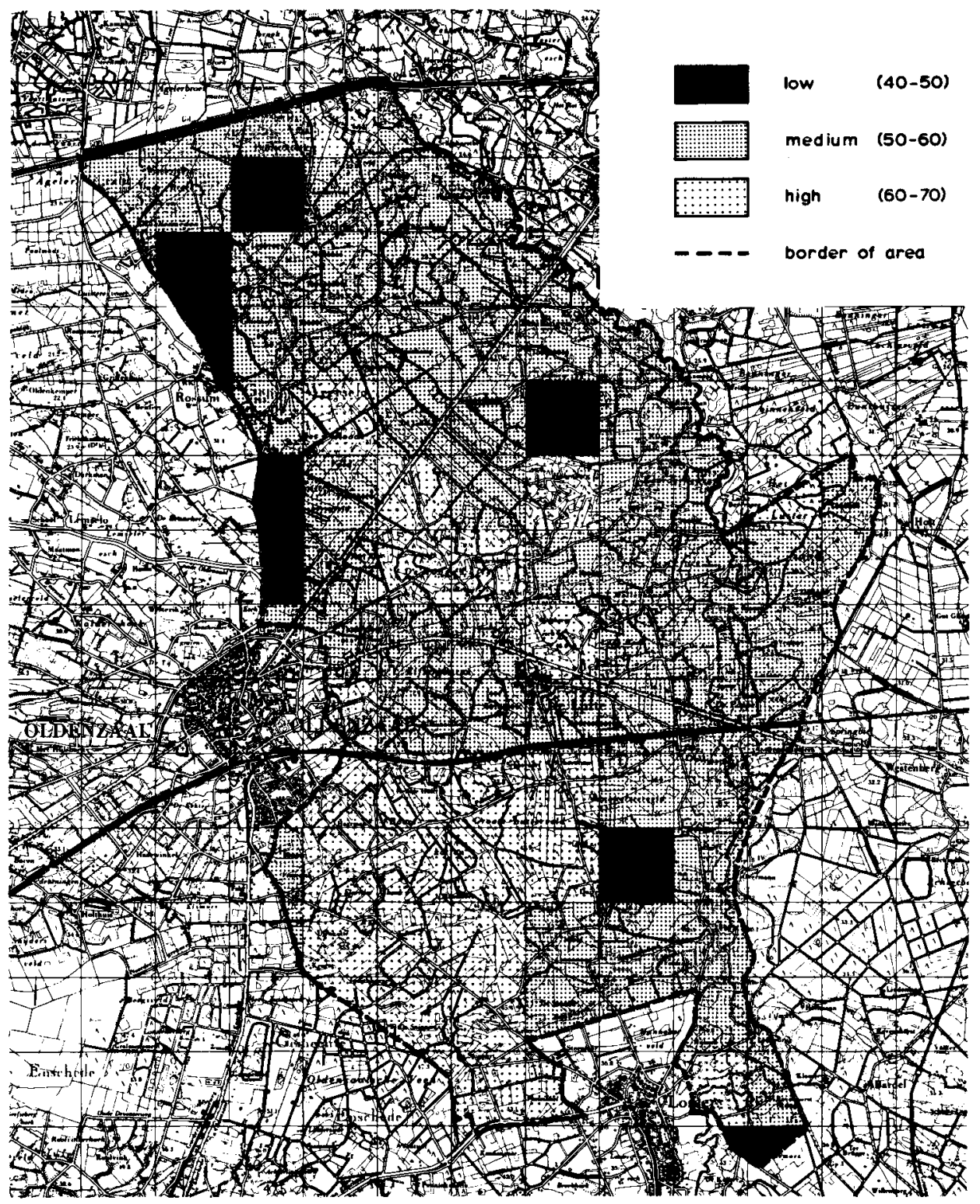

Fig. 3. Suitability potentials for driving for pleasure, based on supply (Fig. 1) and demand (Fig. 2), in the Volthe-De Lutte area (after Anon., 1971). 
H. N. VAN LIER

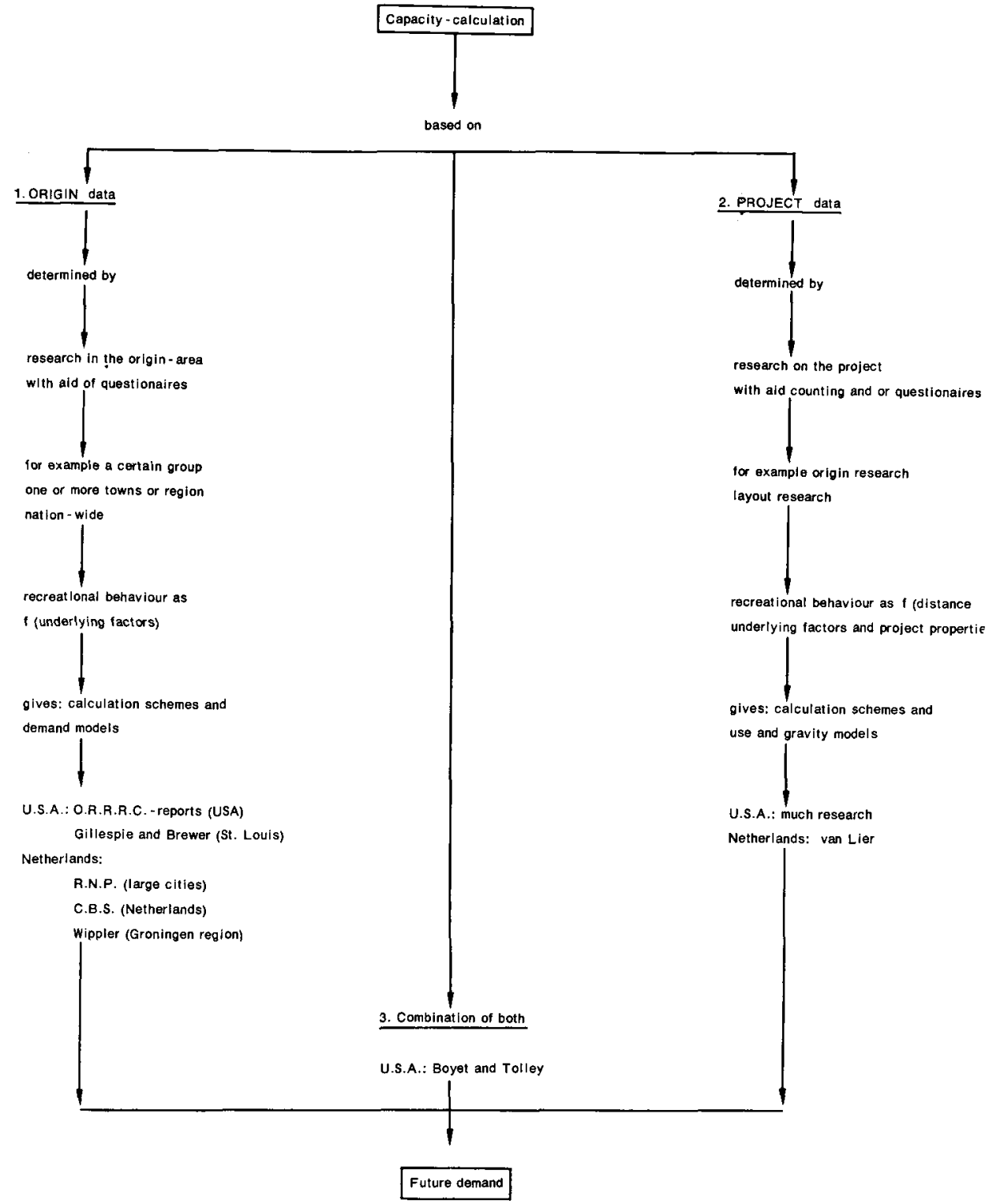

Fig. 4. Scheme of three methods which can be used in demand analyses for capacity calculations of outdoor recreation projects (after van Lier, 1970b).

\section{Demand analysis}

In studies on demand calculations two major groups are to be distinguished (see Fig. 4): - demand studies based on origin data (referred to as origin approach) 
- demand studies based on project data (referred to as project approach)

Origin research can be defined as the determination of the relationship between recreational behavior patterns of the population in a universe, i.e. city, county, state, country, and the underlying socio-economic factors.

Project research can be defined as the determination of origin-destination data (travel distances, time losses) of the visitors on a project in relation with the same underlying characteristics of the recreationists. In the following sections examples of these two types of approach will be given on the level of calculation schemes.

\section{Origin approach}

Example 1 (regional scale, for example a province, county). The demand for a type of outdoor recreation in a region and for a certain year is calculated according the scheme given in Fig. 5. This calculation is necessary to be able to take measures in creating new facilities or improving existing ones. In this case the location, number, capacity and layout of the different projects is not yet taken into account.

As indicated in the scheme the results of origin studies are applied in this approach.

Example 2 (restricted area, 12,000-15,000 ha). In this approach the capacity for a project with a definite location and for a chosen year is calculated. In this case the location of the project and its type of recreation is known. Besides the above-mentioned figures, resulting from origin studies, the willingness to travel of the recreationists (distance behavior) is also taken into account. An example of this kind of calculations is that for the multipurpose reconstruction scheme 'Lopikerwaard' for the year 1980

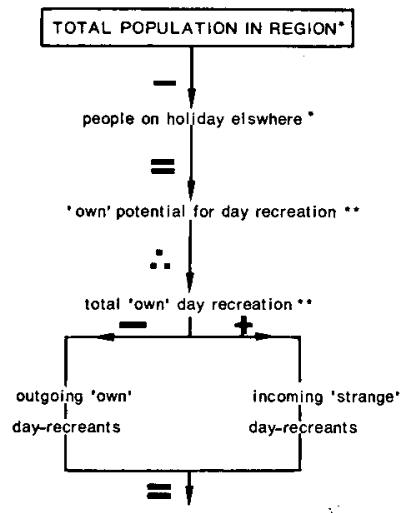

day recreation in region by day reoiean

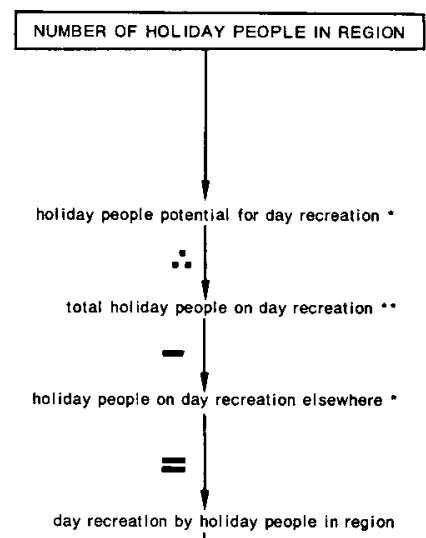

day recreat lon by hol iday people in region

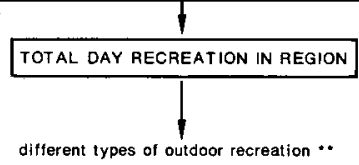

- own calculations

* research results (R.N.P. 1961; C.B.S., 1966; WIPPLER, 1966; O.R.R.R.C., 1962)

Fig. 5. Schematic approach of the calculation of the demand for a certain type of outdoor day recreation on a regional scale (after van Lier, 1970b). 
Table 4. Expected number of recreationists on the fifth busiest day in the Lopikerwaard in 1980 for a certain capacity $(X)$ and for four types of outdoor recreation (after Bergman, 1971)

\begin{tabular}{lcc}
\hline Type of outdoor recreation & $\begin{array}{l}\mathrm{X}=\text { chosen minimum } \\
\text { capacity }\end{array}$ & $\underset{\text { visitors }}{\sum R_{A}}=$ number of \\
Land recreation & 1.000 & 10.500 \\
Water recreation & 8.000 & 15.194 \\
Driving for pleasure & 12.000 & 18.506 \\
Fishing & 2.000 & 2.029 \\
Total (1980) & 23.000 & 45.229 \\
\hline
\end{tabular}

(Bergman, 1971). This is a project of 14,000 ha. In this calculation the following data handling takes place:

- prognosis of population: estimations of the number of inhabitants for each town (Anon., 1970)

- distance zones: constructed by circles from the four 'corners' of the area (shape is more or less rectangular)

- participation index: data from origin research were used, in this case $37 \%, 30 \%$ or $23 \%$, depending on the level of urbanization (Anon., 1966; Wippler, 1966; Anon., 1961)

- distribution of the recreationists over some types of outdoor recreation within the project: known distribution of the recreationists in the province of Utrecht in which 'Lopikerwaard' is situated (Roelfsema and du Rieu, 1969)

- distance characteristics: distance functions constructed from origin studies (Anon., 1969)

- corrections for alternative opportunities: an inventory of existing and certainly to come to alternative sites (Anon., 1970). Each of the alternative sites was given a rating equal to the (measured or planned) capacity of that specific project.

For calculation of the number of visitors in 1980 the following formula was used:

$$
\mathrm{R}_{\mathrm{VA}}=\mathrm{R}_{\Lambda} \frac{\mathrm{X}}{\mathrm{X}+\mathrm{g}_{\mathrm{v}}}
$$

where:

$\mathrm{R}_{\mathrm{A}}=$ number of recreationists visiting the Lopikerwaard in 1980, given per town, per distance class and per type of outdoor recreation

$\mathrm{R}_{\mathrm{VA}}=$ number of recreationists per town, per distance class and per type of outdoor recreation

$\mathrm{X}==$ chosen minimum capacity for a certain type of outdoor recreation in the Lopikerwaard

$\mathrm{g}_{\mathrm{v}}=$ known capacity of the alternative sites and per type of outdoor recreation

Table 4 shows the results of the calculations.

\section{Project approach}

In sequence of increasing refinement the capacity calculations can be made by calculation schemes, use models and gravity models. Calculation schemes are procedures of demand estimation, mostly based on known distance functions. Use models are mathe- 
matical models in which the present or future demand for a certain project is given in relation with present or future socio-economic factors and project properties. Gravity models are mathematical models giving the relationship (interaction) between poles of recreationists (generations) and projects offering recreation (absorptions).

In the Netherlands only some calculation schemes and gravity models have been developed.

The calculation schemes are based on distance functions, which are determined by means of an origin research of the visitors to an existing project (van Lier, 1969/70):

a. A cumulative visit - distance function: in this function the visit to the project is measured per distance class after which the cumulative percentage distribution over the classes is related to the mean distance per distance class.

b. A relative visit - distance function: in this function the relative visit of each origin is related to the distance.

In Fig. 6 an example of both functions is given.

The general equation of the first relation (a) is:

$$
\mathrm{y}_{\mathrm{c}}=100\left(1-\mathrm{e}^{-\mathrm{kx}}\right)
$$

where:

$$
\begin{aligned}
& y_{c}=\text { cumulative distribution of visit }(\% / 0) \\
& \mathrm{e}=\text { base of natural system of logarithms } \\
& \mathrm{k}=\text { coefficient } \\
& \mathrm{x}=\text { mean distance }
\end{aligned}
$$

From this equation the sphere of influence is calculated. This sphere of influence is an area characterized by the maximum distance travelled by $90 \%$ of the visitors. This $90 \%$ level is $85 \mathrm{~km}$ in the example of Fig. 6.

The general equation of the second relation (b) is:

$$
\mathrm{y}_{\mathrm{h}}=\mathrm{e}^{(-\mathrm{ax}+\mathrm{b})}+\mathrm{c}
$$

where:

$\mathrm{y}_{\mathrm{h}}=$ the relative visit per town $=100 \mathrm{~V} / \mathrm{P}(\mathrm{V}=$ number of visitors per town; $\mathbf{P}=$ number of inhabitants per town)

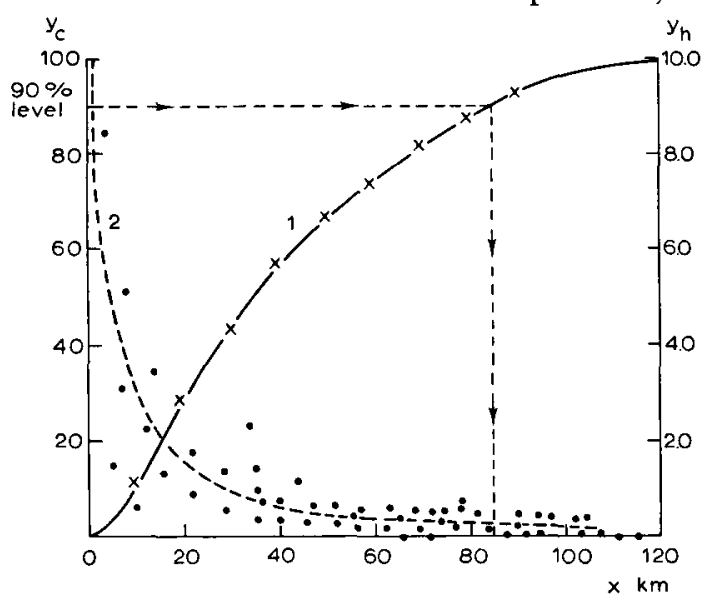

Fig. 6. Theoretical example of the relation between cumulative percentage of visit ( $y_{c}$, Curve 1), the relative visit per origin ( $y_{g}$, Curve 2) and the mean distance $(x)$ for an outdoor recreation project (after van Lier, 1969/70). 
e $\quad=$ base of natural system of logarithms

$\mathrm{a}, \mathrm{b}, \mathrm{c}=$ coefficients

$\mathrm{x} \quad=$ mean distance

The formula can be written with $\mathrm{D}$ as the mean distance over roads as:

$100 \mathrm{~V} / \mathrm{P}=\mathrm{e}^{-\mathrm{aD}+\mathrm{b}}+\mathrm{c}$

or

$$
\mathrm{V}=\frac{1}{100} \cdot \mathrm{P}\left(\mathrm{e}^{-\mathrm{a} D+\mathrm{b}}+\mathrm{c}\right)
$$

so

$$
\mathrm{V}=\frac{\mathrm{P}}{100} \mathrm{e}^{-\mathrm{aD}+\mathrm{b}}+\frac{\mathrm{P} . \mathrm{c}}{100}
$$

This relation is used for the calculation of the total number of visitors of the origin areas at a distance $\mathrm{D}$ and the (estimated or known) population $\mathrm{P}$. This procedure can be simplified by using distance zones instead of towns. An example of this procedure is given for recreation on inland beaches in Fig. 7.

Distance functions have also been derived (for the multipurpose project Lopikerwaard) for other types of outdoor recreation as fishing, driving for pleasure and recreation on beaches along rivers (van Keulen, 1970; Bakker, 1971).

Fishing. Data on the origin of anglers are used for the determination of the distance functions. The functions are given in Fig. 8A.

The formula for the cumulative visit $(\%)$ can be given by:

$$
\mathrm{y}_{\mathrm{c}}=100 .\left(1-\mathrm{e}^{-0.058 \mathrm{x}}\right) \quad\left(\mathrm{r}^{2}=0.98\right)
$$

(for symbols see Eq. 2).

The formula, as also Fig. 8, shows that the sphere of influence (based on the $90 \%$ level) goes to about $40 \mathrm{~km}$ air distance, or $50 \mathrm{~km}$ road distance. For $40 \mathrm{~km}$ air distance the $100 \mathrm{~V} / \mathrm{P}$ number is 0.1 . The formula for the relative visit is:

$$
\mathrm{y}_{\mathrm{h}}=9.159 \mathrm{e}^{-0.36 \mathrm{x}}+0.95 \quad\left(\mathrm{r}^{2}=0.94\right)
$$

(for symbols see Eq. 3).

Driving for pleasure. The distance functions are shown in Fig. 8B. The formulae are:

$$
\begin{aligned}
& \mathrm{y}_{\mathrm{c}}=2.079 \mathrm{x} \quad\left(\mathrm{r}^{2}=0.98\right) \\
& \mathrm{y}_{\mathrm{h}}=13.13 \mathrm{e}^{-0.222 \mathrm{x}}+0.09 \quad\left(\mathrm{r}^{2}=0.99\right)
\end{aligned}
$$

From the figure and the formulae it is clear that the sphere of influence is $43 \mathrm{~km}$ air distance. The $100 \mathrm{~V} / \mathrm{P}$ ratio is at that distance 0.1 .

Recreation on beaches along the River Lek. The distance functions are shown in Fig. $8 \mathrm{C}$. The formulae are:

$$
\begin{aligned}
& y_{c}=100\left(1-e^{-0.106 x}\right) \quad\left(r^{2}=0.97\right) \\
& y_{h}=689 e^{-0.823 x}+7.451 \quad\left(r^{2}=0.93\right)
\end{aligned}
$$

The sphere of influence is $23 \mathrm{~km}$, with a $100 \mathrm{~V} / \mathrm{P}$ ratio of 0.06 at that distance.

\section{Gravity model}

The gravity model has its origin in traffic studies. Recently it is also used for recreation studies. The model is based on the gravitation law of Newton: two bodies attract each 


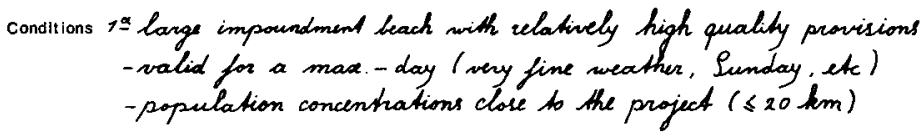

Application

Determine for each orlgin $V:{ }_{D}^{P}\{100 \mathrm{~V} / P$ \{rom curve $\} \rightarrow V_{i} \rightarrow$ total vlsit: $V_{\text {total }}=1.12 V_{n}=1.12 \Sigma \sum_{i=1}^{n} V_{i}$

in sequence:

- determine for each munlcipality: $P_{i}$ en $D_{i}$

- construct zones (based upon $D$; see column 1 and 2)

- determine for each zone $\Sigma_{j=1}^{k} P_{j}$; fill out in column 3

- multiply with translormed $y_{2}$ (column 4)

- summation of the $V_{i}$ 's gives $V_{n}=\sum_{i=1}^{M} v_{i}$ (column 5)

- total visit: $v_{\text {total }}=1.12 \times v_{n}$

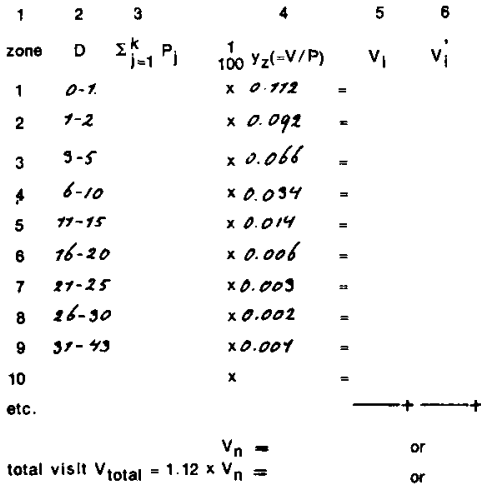

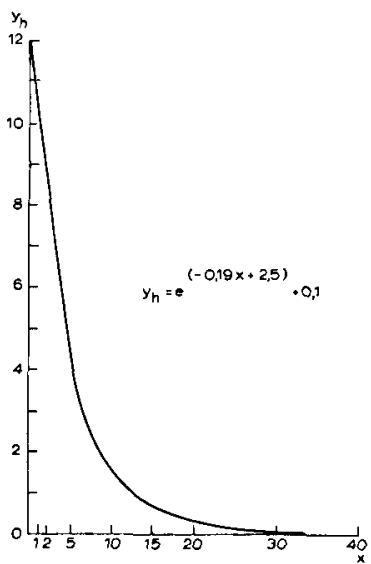

$$
\begin{aligned}
& \text { Remarks: } v_{i}^{\prime} \text { = corrected } v_{i} \text {; can be used } \\
& \text { under known special circumstances for } \\
& \text { certain origins: for example a municlpa- } \\
& \text { lity with a high } P \text { but also a good swim- } \\
& \text { ming accommodation } \rightarrow v_{i}<V_{j} \text {, etc. }
\end{aligned}
$$

Fig. 7. Example of a scheme for the calculation of the future number of visitors to an outdoor recreation project. The pertinent values have been written in for condition 1a, one of the 6 types taken into account for this project (after van Lier, 1969/70). 

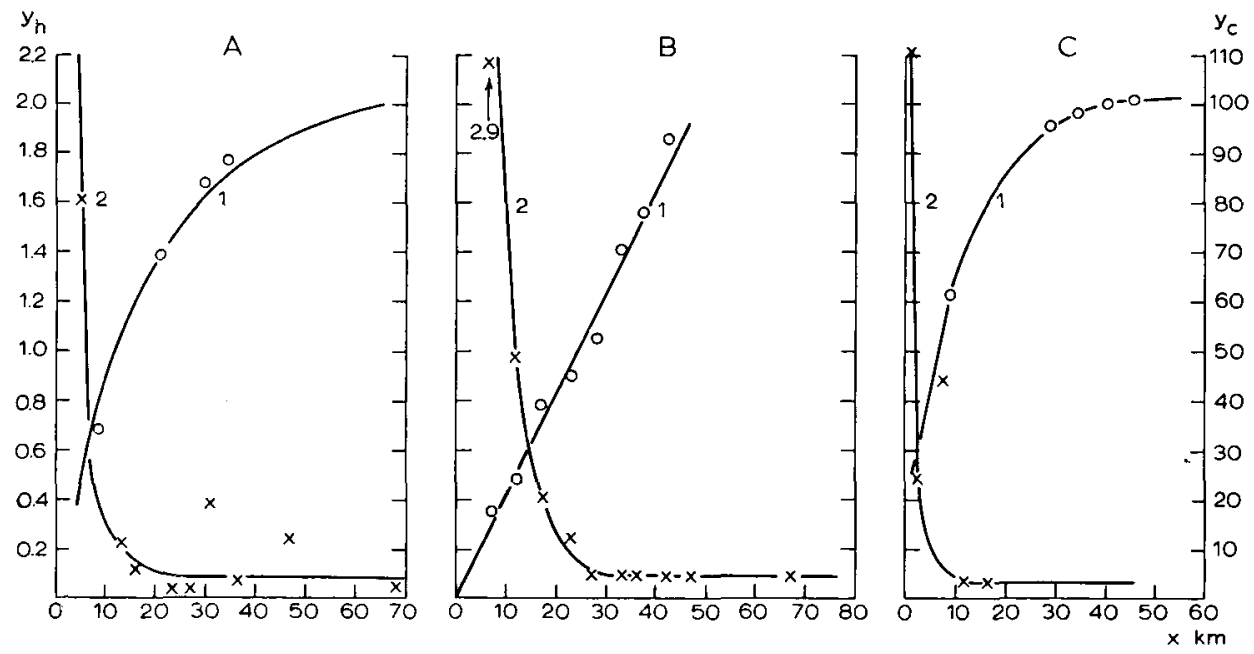

Fig. 8. Relation between the cumulative percentage of visit ( $y_{c}$, Curve 1), the relative visit ( $y_{h}$, Cutve 2) and the air distance $(x)$ for fishing $(A)$, driving for pleasure $(B)$ and swimming in the River Lek (C) for the season 1969 and 1970 (after van Keulen, 1970 and Bakker, 1971).

other with a force which is directly proportional to the mass of the bodies $\left(m_{1}\right.$ and $\left.m_{2}\right)$ and inversely proportional to the square of their mutual distance $D$. Written as a formula:

$$
\mathrm{F}=\mathrm{G} \frac{\mathrm{m}_{1} \cdot \mathrm{m}_{2}}{\mathrm{D}^{2}}
$$

where:

$\mathrm{F} \quad=$ attraction force between two bodies

$\mathrm{m}_{1}, \mathrm{~m}_{2}=$ mass of the bodies

$\mathrm{G}=$ constant of gravitation

$\mathrm{D}=$ distance between the bodies

In the models for recreational traffic other properties are used for $m_{1}$ and $m_{2}$ as the number of inhabitants, the attractivity, etc. The traffic between a number of areas (or zones) can be given for a general model based on origin destination research as:

$$
\mathrm{V}_{\mathrm{MN}}=\mathrm{c} \cdot \frac{\mathrm{P}_{\mathrm{M}} \cdot \mathrm{PN}_{\mathrm{N}}}{\left(\mathrm{D}_{\mathrm{MN}}\right)^{\mathrm{n}}} \cdot \mathrm{a}
$$

where:

$\mathrm{V}_{\mathrm{MN}}=$ number of trips between zone $\mathrm{M}$ and zone $\mathrm{N}$

$P_{M}, P_{N}=$ traffic production of zone $M$ and zone $N$, respectively

$\mathrm{D}_{\mathrm{MN}}=$ distance between zone $\mathrm{M}$ and zone $\mathrm{N}$

c $\quad=$ constant

$\mathrm{a}$ and $\mathrm{n}=$ empirical constants

A gravity model for recreational traffic can be given by the following formula (Ellis and Van Doren, 1966): 
- for pairwise interactions

$$
I_{i j}=G \frac{P_{i} A_{i}}{\left(T D_{i j}\right)^{b}}
$$

- for interaction between more projects (multiple destination/multiple origin)

$$
I_{i j}=k \frac{P_{i} A_{j} /\left(T D_{i j}\right)^{b}}{\sum_{j=1}^{J} A_{i} /\left(T D_{i j}\right)^{b}}
$$

where:

$\mathrm{I}_{\mathrm{i} j} \quad=$ interaction between $\mathrm{i}$ and $\mathbf{j}$

$\mathrm{k}=$ constant

$\mathrm{P}_{\mathrm{i}} \quad=$ population of origin $\mathrm{i}$

$A_{j}=$ attraction index of distance $j$

$T D_{i j}=$ minimum time-distance on route $i j$

$\mathrm{J}=$ total number of destinations

$\mathrm{b}=$ exponent

In the model three factors can be distinguished (Niedercorn and Bechdolt, 1969):

- an origin factor - $P_{i}$ (generation)

- a destination factor - $A_{i}$ (absorption)

- a linkage factor - $\mathrm{TD}_{\mathrm{i}}$ (time-distance)

The origin factor is dealing with the variables of the inhabitants of the origin causing recreational traffic. The most important indication is the number of inhabitants. Other indications can be: mobility, urbanization, etc. This generation factor can also be given by a special model (regression model), a kind of demand model without distance as a variable.

The destination factor or absorption gives the attractivity of the destination. This is equal to the relative attractivity of the project in relation to alternatives. It can be expressed as an attraction index.

The linkage factor (resistance) can be given either by the distance or by travel times between origin and destination.

In the Netherlands the gravity model has been used for inland beach recreation (van Lier and van Keulen, 1970). Two models have been calculated. The first model was comparable to the model of Ellis and van Doren (1966, see Eq. 15). In the second model, the resistance has been expressed as a distance function (see Eq. 3):

$$
g_{i} \cdot I_{i j}=g_{i} \frac{A_{j} e^{-b D_{i j}}}{\sum_{j=1}^{J} A_{j} \cdot e^{-b D_{i j}}}
$$

where:

$\mathrm{g}_{\mathrm{i}}=$ the total number of inland beach visitors from origin $\mathrm{i}$

$I_{i j}=$ percentage of visitors from origin $i$ visiting inland beach $j$

$A_{j}=$ attraction index of inland beach $j$; with $\sum_{i=1}^{J} A=1.0$ 
Table 5. Results of the calculations of two gravity models borvisits to inland beaches in the province of Drenthe on a fine Sunday in 1967 (after van Lier and van Keulen, 1970).

\begin{tabular}{lcc}
\hline Site & $\begin{array}{l}\text { Model with }\left(\mathbf{D}_{\mathrm{ij}}\right)^{\mathrm{b}} \\
\text { (Eq. 15) } \\
\text { attraction index }\end{array}$ & $\begin{array}{l}\text { Model with } \mathrm{e}^{-\mathrm{bD}_{\mathrm{ij}}} \\
\text { (Eq. 16) }^{\text {attraction index }}\end{array}$ \\
Kibbelkoele & 0.41 & 0.43 \\
Tijnaarlo & 0.08 & 0.07 \\
Hildenberg & 0.06 & 0.07 \\
Loomeer & 0.17 & 0.18 \\
Ieberenplas & 0.17 & 0.17 \\
Hemelrijk & 0.09 & 0.09 \\
Constant b & 2.28 & 0.08 \\
Minimum sum of squares & 2474.73 & 2424.72 \\
R2 & 0.70 & 0.70 \\
\hline
\end{tabular}

$$
\begin{aligned}
& \mathrm{D}_{\mathrm{i}} \mathrm{i}=\text { distance between } \mathbf{i} \text { and } \mathbf{j} \\
& \mathrm{b}=\text { exponent }
\end{aligned}
$$

The models were calculated with origin data of six inland beaches in the province of Drenthe for a very good Sunday. The results are given in Table 5.

The models can be used in the following way. In the existing situation the interactions are determined (by means of an origin-destination research). Then the attraction indices $\left(A_{j}\right)$ and the coefficient of the distance function (b) are calculated for the existing projects (see Table 5). If in this region a new project is planned, the attraction index of the new project $\left(A_{n}\right)$ is estimated by a comparison with those of the already existing projects. The old attraction indices are then corrected by means of the following equation:

$$
\mathrm{A}_{\mathrm{p}}{ }^{\prime}=\frac{\mathrm{A}_{\mathrm{p}}}{1+\mathrm{A}_{\mathrm{n}} /\left(1-\mathrm{A}_{\mathrm{n}}\right)}
$$

where:

$A_{\mathrm{p}}=$ attraction index of existing project $\mathrm{p}$ in the old situation

$\mathrm{A}_{\mathrm{p}}{ }^{\prime}=$ attraction index of existing project $\mathrm{p}$ in the new situation (with a new project in the region)

$A_{\mathbf{n}}=$ attraction index of the new project

With the new indices the new interactions can be calculated. Summation of these interactions gives an estimation of the total number of visitors to the new project.

\section{Analysis of the relation between visit and weather}

In the Netherlands diagrams exist giving the relationship between either a personal evaluation of the weather (from 0 to 10 ) by the visitors, or the actual number of visitors, and meteorological data. Examples are diagrams by the Royal Netherlands Meteorological Institute (Delver, 1951-1954; den Tonkelaar, 1968) for the coast of the North Sea, and those by Smedema (1969) for visits to inland beaches. Based on these diagrams a theoretical diagram was constructed giving the relation between $\mathrm{O}$. W. values $(=$ out- 


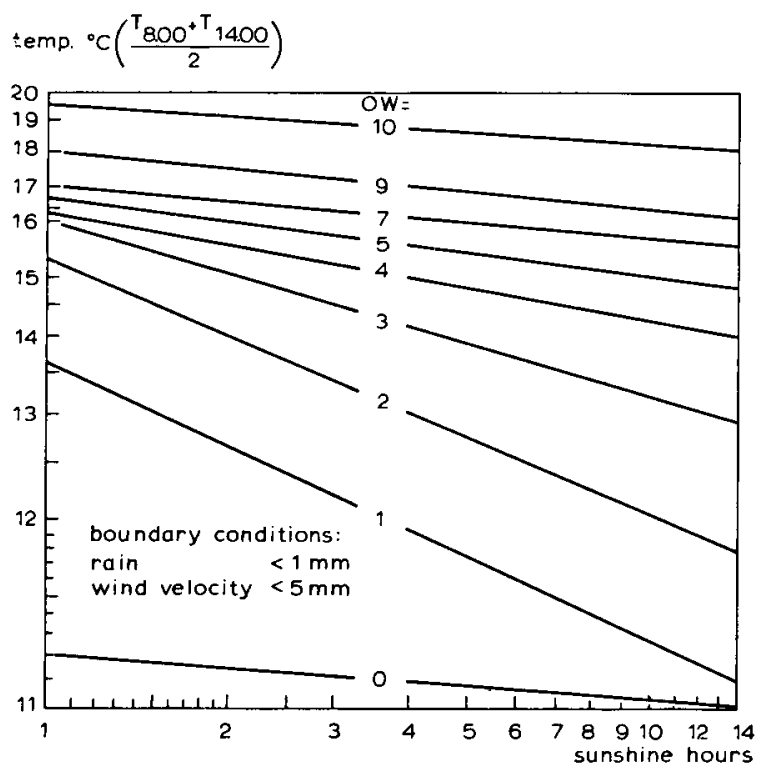

Fig. 9. Relation between O.W. (Outdoor recreation - Weather) values and mean temperature $(8.00$ p.m. - 14.00 a.m.), hours, of sushine, rain and wind velocity, for inland beaches in the Netherlands (after van Lier, 1970c).

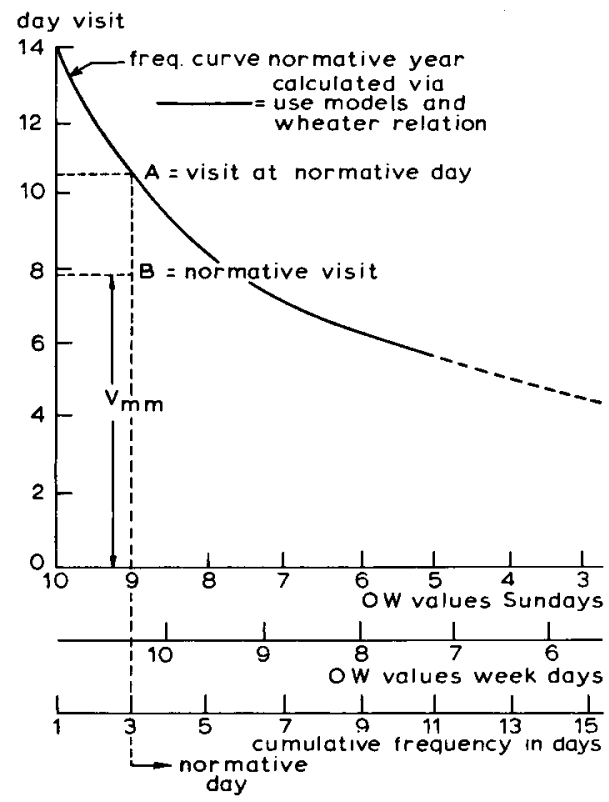

Fig. 10. Schematic frequency curve of the day visit on a recreation project versus outdoor recreation - weather (OW) values and their cumulative frequency in days, with the derivation of the visit at the normative day and, via the maximum momentary visit $\left(V_{\mathrm{mm}}\right)$, the normative visit (after van Lier, 1970c).

door recreation - weather values) and the mean temperature between 8.00 p.m. and 14.00 a.m., sunshine hours and boundary conditions of rain and wind velocity (Fig. 9). With the aid of this diagram the number of days with certain $O$. W. values are calculated for the summer season (van Lier, 1970c). 
To determine the capacity of the elements of recreation projects the normative number of visitors has to be known. Thus a frequency curve of day visits in the normative year is needed and a choice of the normative day has to be made. From the known time distribution of the visitors during the normative day, the maximum momentary visit (the maximum number of visitors present at one moment) as a percentage of the day visit can be concluded. A reasoned choice of a certain percentage of this maximum $\left(V_{m m}\right)$ gives the design capacity and a basis to design the road system, parking places, water area, beach area, picnic sites and facilities, playgrounds, etc. A scheme is given in Fig. 10.

The procedure gives problems when the frequency curve is very steep (visit strongly fluctuating from day to day) or very flat (nearly constant visit).

\section{Benefit-cost analyses}

There are arguments pro and contra as regards the use of benefit-cost analysis for outdoor recreation projects.

Against an economic approach of the benefits originating from recreation projects is the difficulty, if not the impossibility, of expressing aesthetic and personal experiences in monetary terms. On the other hand the same parameters are used when evaluating investments in roads, accidents, etc.

For the evaluation of time and money savings resulting from the construction of a new project, the principle of the willingness to pay and the consumers surplus derived from this has been introduced by Hotelling (1949) and Clawson and Knetsch (1966).

Klaassen (1968) distinguished between primary and secondary benefits. In this conception the primary benefits are the increase of happiness and health and the secondary ones the increase in labor productivity as a result of these better physical and psychological conditions. The primary benefits are difficult to measure, the secondary ones on the contrary, are, measurable.

In principle secondary benefits can be measured in four ways (Locht, 1970):

- system analysis (resource studies for multiple land use)

- consumer surplus calculations

- cost savings calculations

- supply and demand analyses.

Summarized, the scheme in Fig. 11 can be made.

The principle of a consumers surplus calculation is given in Fig. 12 as it was applied to the inland beach Ermerzand in the rural reconstruction area Sleenerstroom (van Lier, 1969/1970).

\section{Layout research}

About the layout of a new outdoor recreation project two questions can be raised:

- What types of facilities have to be built into the project?

- What number, size and arrangement of the chosen facilities is necessary?

To answer these questions it is necessary to know:

- the use of the different facilities in existing projects

- the technical possibilities (limitations or restrictions, boundary conditions)

Concerning the use of the elements by the visitors, research is necessary depending on relevant factors as: 

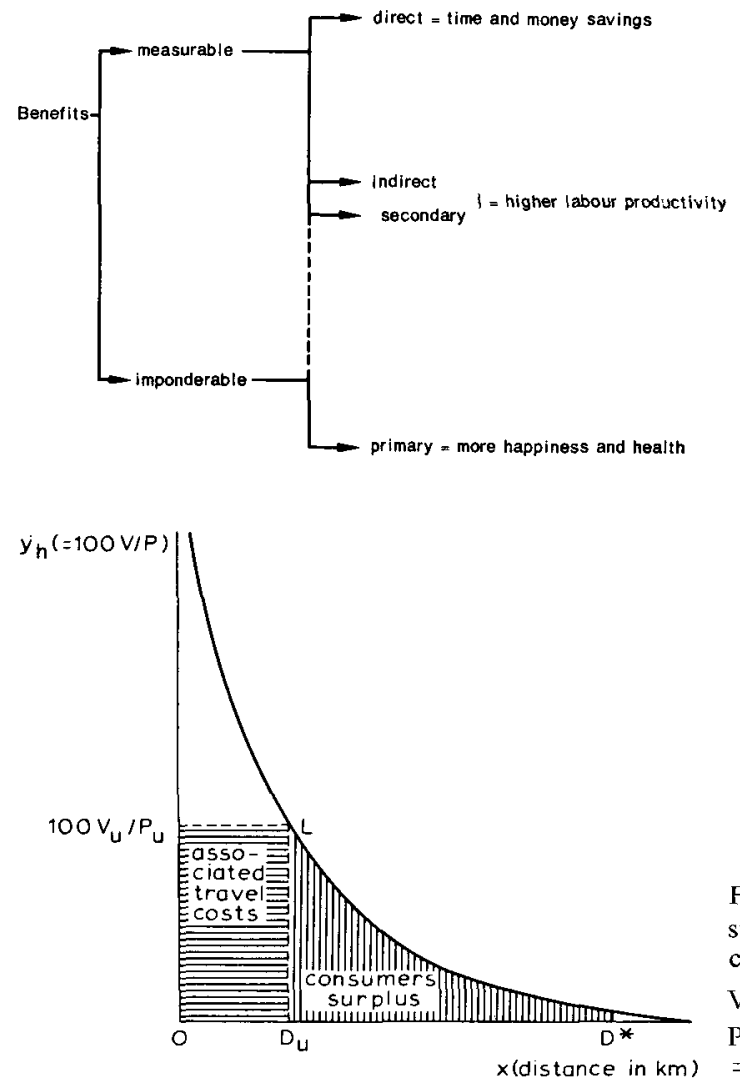

Fig. 11. Scheme of benefits coming from a recreation project.
Fig. 12. Demand curve and consumers surplus for an inland beach; $\mathbf{D}_{\mathrm{u}}=$ distance origin $U$ to site; $D^{*}=$ ceiling distance; $\mathrm{V}_{\mathrm{u}}^{\mathrm{u}}=$ number of visitors from origin $\mathrm{U}$; $\mathrm{P}_{\mathrm{u}}=$ population in origin $\mathrm{U} ; 100 \mathrm{~V}_{\mathrm{u}} / \mathrm{P}_{\mathrm{u}}$ $=$ relative visit from origin $\mathbf{U}$.

- accessibility of the elements

- furnishing and other provisions

- distances between the elements

- size of the elements

- characteristics of the visitors: time of arrival; kind, composition and size of group; income, etc.; used equipment, etc.

This type of study has been done for the artificial lake Veluwemeer bordering the newly reclaimed IJsselmeer polders (ter Haar, 1968). One of the problems in this kind of research is the possibility of a mutation in recreational behavior. This might happen if, for example, new recreation equipment is coming on the market. For planning of new projects it is necessary to anticipate such kinds of delvelopment. This can be done, for example, by keeping a spare area or by phasing the project. Most of the research on layout problems has been limited to extrapolation into the future of actual measured behavior of visitors. In its most simple way only counting of the number of visitors per element of a project is done at a number of time periods per day. From this results a figure referred to as 'attendance level'. This type of layout research can be repeated on different days, among other things for the determination of capacity standards and 


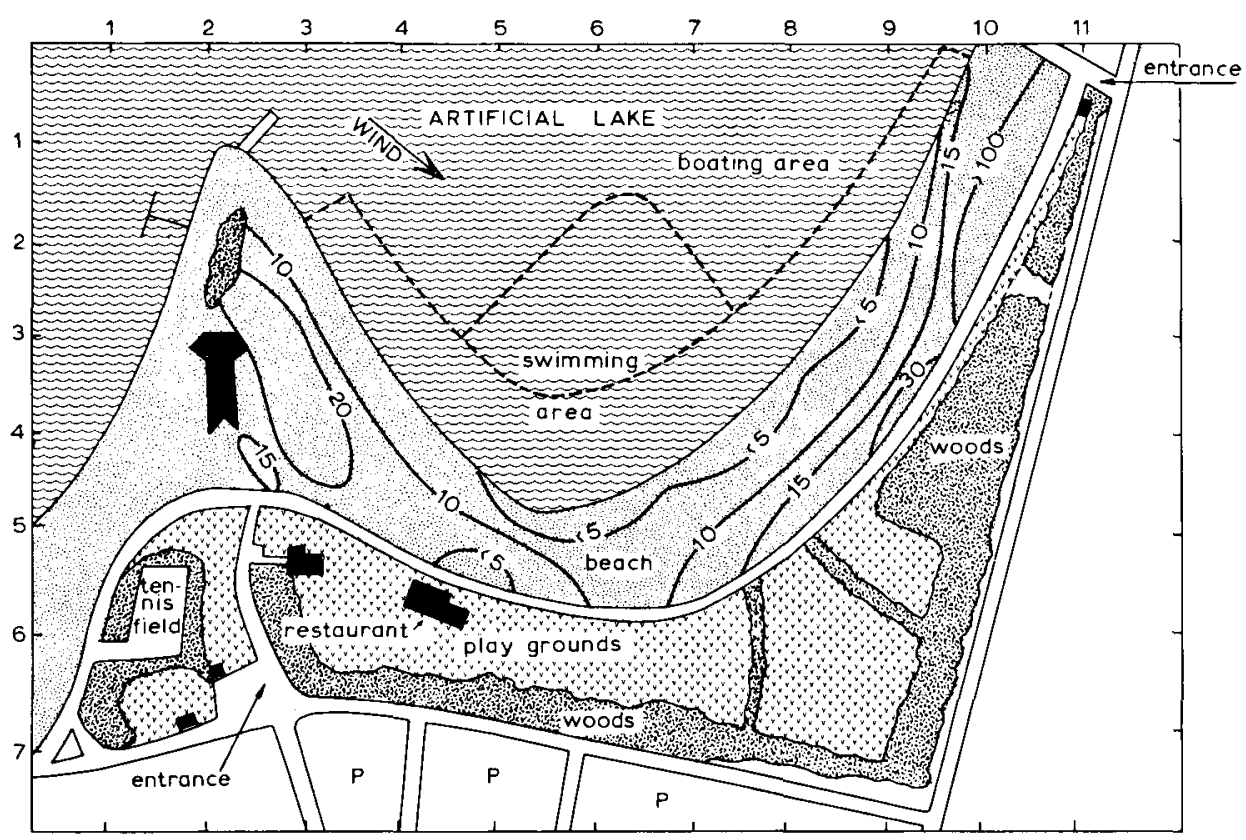

Fig. 13. Isospace lines ( $\mathrm{m}^{2}$ per person) at an inland beach (Beekse Bergen, 2 June 1968 at $14 \mathrm{~h} 00$. Easterly wind $3.5 \mathrm{~m} / \mathrm{sec}$; air temperature $16^{\circ} \mathrm{C}$, slightly cloudy, 4 hours sunshine, no rain).

weather relationships. An example of this is given for an inland beach in Fig. 13.

The counting of the visitors has been done by visual counting and by aerial photography. In the figure isospace lines (lines connecting points with the same available area in square meters per visitors) are drawn. From this figure it can be concluded that: - the attendance is decreasing (and therefore the recreation space per visitor is increasing) as the walking distance from the entrance to the element is increasing.

- the highest attendances are found at border situations such as beach $\leftrightarrow$ water; playground $\leftrightarrow$ beach; playground $\leftrightarrow$ trees and woods, etc. (This border, or transition, effect is known from various disciplines, such as ecology, wildlife, landscaping.)

Studies on the technical possibilities often include soil science, hydrology, biology and environmental control. Without doubt a lot of knowledge in former times gained for the purpose of wood and timber production can with some adaptations be applied for recreation projects. This, however, does not exclude the necessity for research regarding the design criteria of land drainage, top layer conditions, soil profiles and so on, for recreational use.

This type of criteria has been developed for a future recreation area (user-oriented) of 800 ha in the neighborhood of Amsterdam, the Twiskepolder. This polder is an area with a peat layer of 2 to $3 \mathrm{~m}$ overlying clay and sand. The sand from the subsoil has been removed for the construction of highways, so there is now a lake of 70 ha. The removed top layer (a mixture of clay and peat) is put into depots to be used as playgrounds and woods (van Wijk and van den Hurk, 1971). The criteria are given in Table 6.

With the aid of the conditions of Table 6 it is possible to determine the measeures to be taken for drainage and soil improvement to make the soil suitable for outdoor re- 
Table 6. Soil and hydrological conditions required for playgrounds and woods (after van Wijk and van den Hurk, 1971)

\begin{tabular}{|c|c|c|c|}
\hline Intended use & Profile & Hydrology & Special requirements \\
\hline Playgrounds & $\begin{array}{l}\text { upper layer } \\
0.50 \text { to } 0.60 \mathrm{~m} \\
\text { with a good } \\
\text { permeability and } \\
\text { a well-bearing } \\
\text { top layer }\end{array}$ & $\begin{array}{l}\text { water-table } \\
>0.30 \mathrm{~m} \\
\text { below surface }\end{array}$ & $\begin{array}{l}\text { top layer 'clean', non-slippery, not } \\
\text { too hard or too soft; } \\
\text { a small degree } \\
\text { of relief is permitted }\end{array}$ \\
\hline $\begin{array}{l}\text { Woods with } \\
\text { different kinds } \\
\text { of deciduous } \\
\text { trees }\end{array}$ & $\begin{array}{l}\text { upper layer } \\
0.50 \text { to } 0.60 \mathrm{~m} \\
\text { mostly mineral } \\
\text { without sharp } \\
\text { boundaries }\end{array}$ & $\begin{array}{l}\text { water-table } \\
>0.40 \mathrm{~m} \\
\text { below surface }\end{array}$ & $\begin{array}{l}\text { moist, fairly humic upper } \\
\text { layer; no severe } \\
\text { fluctuation of water table; } \\
\text { pH-KCl over } 4.5 \\
\text { to } 5.0\end{array}$ \\
\hline
\end{tabular}

creation. In Fig. 14 and example is given of the investments in drainage and soil improvement necessary to make playgrounds of suitability class 1 in the Twiskepolder.

Hydrological criteria for camping grounds also are available (Segeren and Sprokholt, 1968). Based on a study of rainfall intensities, the following criteria for the drainage sytem of camping grounds are given as:

- the whole project has to be drained in such a way that an intensity of 0.40 to 0.45 $\mathrm{mm} / \mathrm{min}$ does not give puddles longer than one hour after the beginning of the shower - in the immediate neighborhood of tents and living vans a normative intensity of 0.60 $\mathrm{mm} / \mathrm{min}$ is adopted

Another aspect is pollution control. Research has been done on the water quality of inland beaches. Studies are carried out on the relationship between number of swimmers and the physical, chemical and bacterial pollution of the water. In Fig. 15 some results of these studies are given (van Lier, 1970a).

Besides a determination of the amount of pollution, a comparison has been made between the measured pollution (by sampling) and the calculated one. The pollution was calculated with the formula of Scholte Ubing and Kats (1966), based on:

a. A decreasing curve of ten days:

$$
\mathrm{n}_{\mathrm{t}, 1}=\mathrm{n}_{1} \cdot \mathrm{e}^{-\mathrm{kt}}
$$

where:

$\mathrm{n}_{1}=$ number of bacteria introduced on day 1

$\mathrm{n}_{\mathrm{t}, 1}=$ number of bacteria left over from $\mathrm{n}_{\mathbf{1}}$ after $\mathrm{t}$ days

$\mathrm{k}=-\mathrm{c} \log \mathrm{a} / \log \mathrm{e}=$ constant

e $=$ base of the natural sytem of logarithms

$\mathrm{t}=$ number of days

b. The assumption that a swimmer introduces about $1.8 \times 10^{9}$ bacteria. This gives:

$$
\mathrm{n}_{1}=1.8 \times 10^{3} \mathrm{~B} / \mathrm{I} \text { bacteria } / \mathrm{ml}
$$

where:

$\mathrm{n}_{1}=$ number of bacteria $/ \mathrm{ml}$ at the end of the first day

$\mathrm{B}=$ number of swimmers on day 1

$\mathrm{I}=$ content of the pool (day 1 ) in $\mathrm{m}^{3}$ 


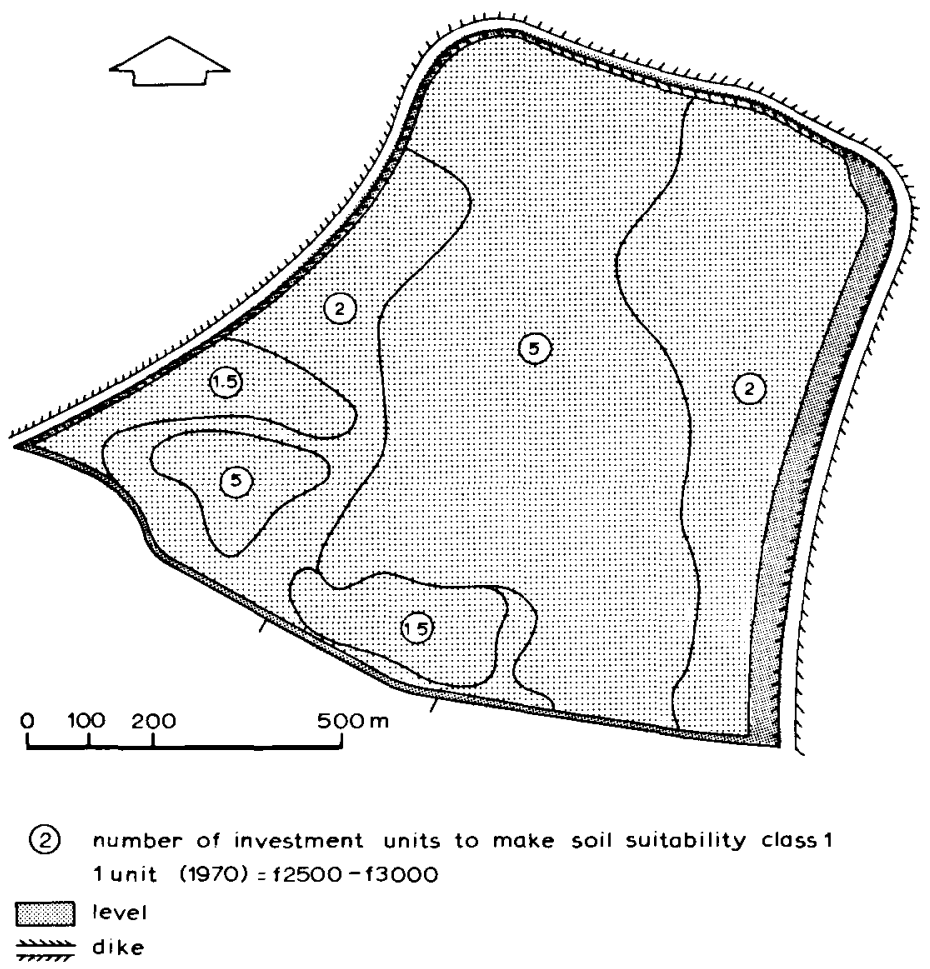

Fig. 14. Investment for drainage and soil improvement measures to ensure a suitability class 1 for playgrounds in the future recreation project Twiskepolder near Amsterdam (after van Wijk and van den Hurk, 1971).

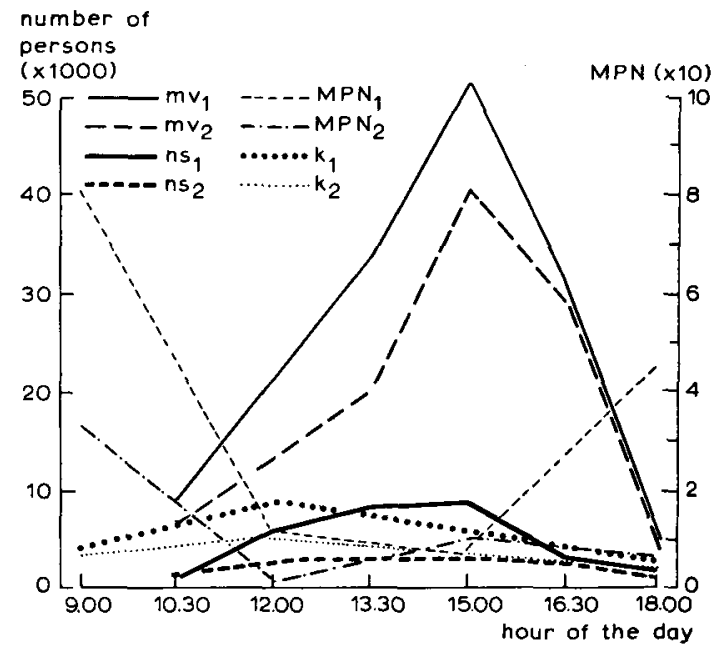

Fig. 15. Momentary visit (mv), number of swimmers (ns), most probable number of bacteria at $44^{\circ} \mathrm{C}$ on agar (MPN) and that at $37{ }^{\circ} \mathrm{C}(\mathrm{k})$ for the inland beach Loofles on Saturday, 10 August, (1) and Sunday, 11 August, 1968 (2) (after van Lier, 1970a). 


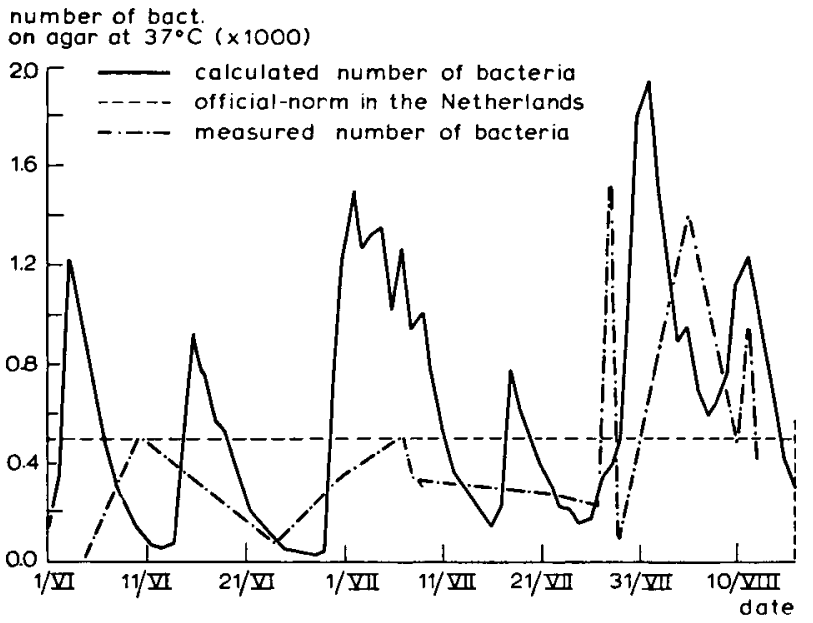

Fig. 16. Measured and calculated number of bacteria in the pool of the inland beach Loofles during 1968 (after van Lier, 1970a).

These two assumptions give:

$$
\begin{aligned}
& \mathrm{N}_{\mathrm{p}}=\mathrm{n}_{\mathrm{p}}+0.77 \mathrm{n}_{\mathrm{p}-1}+0.60 \mathrm{n}_{\mathrm{p}-2}+0.46 \mathrm{n}_{\mathrm{p}-3}+0.34 \mathrm{n}_{\mathrm{p}-4}+0.24 \mathrm{n}_{\mathrm{p}-5}+0.16 \mathrm{n}_{\mathrm{p}-6}+ \\
& +0.10 \mathrm{n}_{\mathrm{p}-7}+0.05 \mathrm{n}_{\mathrm{p}-8}+0.02 \mathrm{n}_{\mathrm{p}-9}
\end{aligned}
$$

where:

$\mathrm{N}_{\mathrm{p}} \quad=$ total number of bacteria at the end of day $\mathrm{P}$

$\mathrm{n}_{\mathrm{p}}=\mathrm{n}_{\mathrm{p}-1} \ldots \mathrm{n}_{\mathrm{p}-9}=$ number of bacteria introduced on day $\mathrm{p}$, day $(\mathrm{p}-1) \ldots$ day $(\mathrm{p}-9)$, respectively.

Based on this formula and the known number of visitors, the numbers of bacteria for two inland beaches Zandenplas and Loofles were calculated. Fig. 16 shows the difference between the calculated and the measured situation.

These results indicate that the applied formula gives a large safety margin for large inland beaches. For small inland beaches the real pollution was found to be more severe than the calculated one. From this it can be concluded that for small pools much more stringent criteria are necessary.

From a hygienic point of view many problems remain unanswered. In natural pools there is justifiable doubt whether the number of bacteria is an acceptable criterion. A better indication would be the amount of Bacterium coli, and more especially Escherichia coli, originating from the human intestine flora.

\section{Future research}

A conspectus was given of some types of research on outdoor recreation in the Netherlands. The aims of these studies are a better allocation of funds and more efficient plans for outdoor recreation projects in rural areas. A special aspect is the relationship of such projects with multipurpose rural reconstruction programs in the Netherlands. Three major groups of problems were mentioned, namely location, capacity and layout. With regard to the investment in this sector research is not yet sufficient to make a justified economic approach possible.

It is therefore thought that the following research is necessary: 
Table 7. Research in the field of outdoor recreation in the Netherland to be continued or to be started

2. Project research
$\begin{aligned} \text { 1.1. } & \begin{array}{l}\text { survey: of already existing data } \\ \text { classification in types } \\ \text { definitions }\end{array} \\ \text { 1.2. } & \text { home-questionnaires: measurement of recreational } \\ & \text { measurement relevant (socio-economic) factors }\end{aligned}$
1. Origin research
$\begin{aligned} & \text { 2.1. } \\ & \text { 2.2. } \begin{array}{l}\text { distance survey: visitors-questionnaires concerning } \\ \text { origin and socio-economic factors of the visitors }\end{array} \\ & \text { 2.3. } \begin{array}{l}\text { layout research: technical aspects } \\ \text { properties of the facilities } \\ \text { relevant factors of the visitors } \\ \text { use of the facilities } \\ \text { preferences }\end{array} \\ & \text { inventory of existing projects }\end{aligned}$

- A nation-wide statistical 'origin' research (extremely important to get a general idea of outdoor recreation patterns)

- An extension of 'project' research (to make construction of use and gravity models possible)

- An extension of layout research (for information on the use of existing facilities and preferences of the visitors, and on the technical possibilities and constraints on behalf of design criteria)

- A development of uniform evaluation systems of the landscape for recreational use.

In Table 7 a conspectus of research to be continued or still to be done in the Netherlands is given. In this table a classification was made according to origin and project research.

\section{References}

Anonymous, 1961. Mensen op zondag. Publ. Rijksdienst natn. Plan 14. Staatsdrukkerij, Den Haag.

Anonymous, 1962. National recreation survey (Study Report 19); Participation in outdoor recreation: factors affecting demand among American adults (Study Report 20). Outdoor Recreation Resource Review Commission. U.S. Government Printing Office, Washington, D.C.

Anonymous, 1966. Vrijetijdsbesteding in Nederland 1962-1963. (Particularly Parts 6 and 8). Centraal Bureau voor de Statistiek. Staatsdrukkerij, Den Haag.

Anonymous, 1969. Recreatie in Twente. Grontmij-Raadgevend Bureau Berenschot, De Bilt.

Anonymous, 1970. Bevolkingsprognose voor 1980 in Utrecht, Noord-Holland en Zuid-Holland. Economisch Technologisch Instituut, Utrecht.

Anonymous, 1971. De landinrichting van het gebied Volthe-De Lutte; verkenning, analyse en modellen. Studiegroep Volthe-De Lutte, Wageningen.

Bakker, J. G., 1971. Toerrijden in de Lopikerwaard. Nota Inst. CultTech. WatHuish. 632.

Bergman, H., 1971. Berekening van de vraag naar openluchtrecreatie; Lopikerwaard. Nota Inst. CultTech. WatHuish. 628.

Bijkerk, C., 1970. Het onderzoek naar openluchtrecreatie. Recreatie 8 (3): 69-82.

Clawson, M. \& H. Knetsch, 1966. Economics of outdoor recreation. John Hopkins Press, Baltimore/ London.

Delver, A., 1952-1955. Strandweerrapporten I-IV. Royal Netherlands Meteorological Institute (KNMI), De Bilt. (Internal report).

Edminster, F. C., 1966. Finding the potentials for rural recreation. Soil Conserv. 32 (3).

Ellis, J. B. \& C. S. van Doren, 1966. A comparative evaluation of gravity and system theory models for state-wide recreational traffic flows. J. reg. Sci. $6(2)$ 
Gillespie, G. A. \& D. Brewer, 1968. Effects of non-price variables upon participation in water-oriented outdoor recreation. Am. J. agric. Econ. 50 (1): 82-90.

Haar, E. ter, 1968. Dagrecreatie langs het Veluwemeer; verslag van een onderzoek. Flevo Ber. (Rijksdienst IJsselmeerpolders) 58.

Helliwell, D. R., 1969. Valuation of wildlife resources. Regional Studies Vol. 3. Pergamon Press, New York.

Hotelling, H., 1949. The economics of public recreation. In: The Prewiss report. An economic study of the monetary evaluation of recreation in the National Parks. U.S. Department of the Interior, Washington, D.C.

Jantsch, E., 1967. Technological forecasting in perspective organisation for economic cooperation and development. Paris.

Kerstens, A. P. C., 1970. Prognose en planning. Openluchtrecreatie in de toekomst. Recreatievoorzieningen 21 (3).

Keulen, J. G. van, 1970. Polderrecreatie. Een verkenning inzake het gebruik van de Lopikerwaard voor openluchtrecreatie. Nota Inst. CultTech. WatHuish. 545.

Kiemstedt, H., 1967 Zur Bewertung der Landschaft für die Erholung. Beiträge zur Landespflege, Sonderheft 1. Stuttgart.

Kiemstedt H., 1969. Eine Bewertungsziffer für die Erholungseignung der Landschaft. Monat. Arch. $f$. Niedersachsen 18 (1): 15-19. Göttingen.

Klaassen, L. H., Social amenities in area economic growth. (Particularly Chapter 7: Recreation, p. 105-120.) OECD, Paris.

Lier, H. N. van, 1968. Strandbadenbezoek 1980 en 2000. Tijdschr. K. Ned. Heide Maatsch. 79 (6).

Lier, H. N. van, 1969/70. Capaciteitsberekening voor nieuw te stichten strandbaden. Recreatievoorzieningen 20(12); 21(1).

Lier, H. N. van, 1970a. Zwemwater in strandbaden. Een onderzoek naar gebruik en kwaliteit van het zwemwater in een tweetal strandbaden tijdens het recreatieseizoen 1968. $\mathrm{H}_{2} \mathrm{O} 3(10)$.

Lier, H. N. van, 1970b. Enkele aspecten van de openluchtrecreatie. Recreatievoorzieningen 21(6).

Lier, H. N. van, 1970c. De (theoretische) opzet tot de capaciteitsberekening van een recreatieobject. Nota Inst. CultTech. WatHuish. 588.

Lier, H. N. van, 1970d. Strandbadrecreatie. Recreatie 8(5).

Lier, H. N. van \& J. G. van Keulen, 1970. Een gravitatiemodel voor recreatieverkeersstromen toegepast op strandbezoek. Recreatievoorzieningen 21(9).

McHarg, J., 1966. Design with Nature. Natural History Press, Garden City, N.Y.

Niedercorn, J. H. \& B. V. Bechdolt Jr., 1969. An economic derivation of the 'Gravity Law' of special interaction. J. reg. Sci. $9(2)$.

Polak, F. L., 1969. Prognostica (abridged ed.). Kluwer, Deventer.

Roelfsema, H. \& F. P. H. du Rieu, 1969. Een onderzoek naar de recreatiespreidingspatronen. Recreatievoorzieningen 21 (4).

Scholte Ubing, D. W. \& W. Kats, 1966. Vervuiling en kwaliteitsbeheer van het water in ondiepe recreatieplassen. Water 50 .

Segeren, W. A. \& W. Sprokholt, 1968. De waterhuishouding van kampeerterreinen. CultTech. Tijdschr. $8(2)$.

Segers, A. J. A. M., 1970. Bepaling van de fysisch-geografische geschiktheid van plattelandsgebieden voor openluchtrecreatie. Nota Inst. CultTech. WatHuish. 574.

Smedema, R. H., 1971. De relatie tussen het bezoek aan strandbaden en weersfactoren. Nota Inst. CultTech. WatHuish. 646.

Tonkelaar, J. den, 1968. Strandweerdiagrammen. Royal Netherlands Meteorological Institute (KNMI), De Bilt. (Internal report.)

Wippler, R., 1966. Vrije tijd buiten. Van Gorcum, Assen.

Wippler, R., 1968. Sociale determinanten van het vrijetijdsgedrag, Thesis, Groningen.

Wijk, A. L. M. van, 1970. Eisen te stellen aan de grond ten behoeve van de aanleg van wegen, paden en strandbaden. Nota Inst. CultTech. WatHuish. (In preparation).

Wijk, A. L. M. van \& J. A. van den Hurk, 1971. Geschiktheid voor speel- en ligweiden en bos. Rapport 1 van de Werkgroep Bodem en Water Twiskepolder. Institute for Land and Water Management Research Wageningen. (Internal report.)

Wijk, C. van, 1970. Een methode ter bepaling van de potentiële mogelijkheden voor diverse vormen van openluchtrecreatie ( + supplement). Nota Inst. CultTech. WatHuish. 594. 